Field Studies. The new laboratory will act as a centre, not only for laboratory research, but also for the organization of field trials, observations of stud and other practices, and for the collection of infornation from all possible sources. Officers of the present Wool Biology Section are now active in this field; in addition, they and others are collaborating in projects known as the 'strain trials', in which the performance of five different strains of merino sheep is being studied at three different localities in the eastern half of Australia. The trial will continue for many years. Such field studies as these are often best interpreted in the light of concurrent work on the smaller, closely controlled groups of animals for which the facilities of the Sheep Biology Laboratory were designed.

Following the lead of institutions like Rothamsted Experimental Station in Britain, the Sheep Biology Laboratory will develop a strong statistical section. Other aspects of its present structure that will be strengthened are the more biochemical and biophysical parts of the work. The exact degree to which it may participate in work of a more-or-less purely genetic nature will depend on its relationship with the newly formed Section of Animal Genetics of the Commonwealth Scientific and Industrial Research Organization, part of which may also be located at Prospect.

\section{BRITISH COMMONWEALTH GEOLOGICAL LIAISON OFFICE}

$\mathrm{D}$ URING the recent nineteenth International Geological Congress at Algiers, the first meeting of the British Commonwealth Committee on Mineral Resources and Geology was held in the British Consulate Office, at which the following representatives of their respective Geological Surveys attended : Mr. C. J. Sullivan (Australia), Dr. J. W. Harrison (Canada), Dr. F. Dixey (the Colonies), Dr. B. C. Roy (India), Dr. N. M. Khan (Pakistan), Dr. A. M. MacGregor (Southern Rhodesia), Dr. L. T. Nel (South Africa), Dr. W. J. Pugh (United Kingdom) and Mr. R. W. Willett (British Commonwealth geological liaisōn officer).

The British Commonwealth Geological Liaison Office and the British Commonwealth Committee on Mineral Resources and Geology were set up on the recommendation of the 1948 Specialist Conference on Mineral Resources and Geology, the purpose and scope of the office being defined in the report of that Conference (Code No. 47-149. London: H.M.S.O., 1949). As a result, the Geological Liaison Office was established in May 1951 at the British Commonwealth Scientific Offices, Africa House, London, and at the same time the present British Commonwealth geological liaison officer, R. W. Willett, of the New Zealand Geological Survey, commenced duties.

The recommendations of the 1948 conference were as follows. (a) Permanent Commonwealth machinery should be set up to promote collaboration and interchange of information between government organizations concerned with the investigation of geology and mineral resources throughout the British Commonwealth. This machinery should take the form of a Committee, to be known as the Committee on Mineral Resources and Geology, with members representative of such organizations from each of the participating countries meeting at intervals of not more than three years in a Commonwealth country. (b) The permanent executive and secretarial work of this Committee should be under the direction of a senior officer with appropriate technical qualifications stationed in London, who would be known as the British Commonwealth geological liaison officer. His duties would include : acting as a liaison officer in matters pertaining to geology and mineral resources for all participating members of the British Commonwealth; taking appropriate action to give effect to the recommendations of the present Conference; and making the preliminary arrangements for the periodical meetings of the Committee.

Dr. W. J. Pugh, director of the Geological Survey of Great Britain, was elected chairman and will now hold office until the Committee meets again, which will be when a suitable and appropriate occasion offers. The Committee reviewed and discussed the annual report of the Geological Liaison Officer, and the progress made in translating into action the original recommendations, and endorsed the action taken; as a result, it recommended the continuance of the Geological Liaison Office along the lines already laid down. The geological liaison officer is appointed for three years, at the end of which period he is replaced by another Commonwealth officer selected and appointed in the same manner. The first annusl report of the Office was presented at a recent meeting of the Committee, and in it the scope and extent of the work of the Office were outlined.

As a background to the work of the Office, a series of reports are being prepared on the mineral resources of the British Commonwealth. These reports present the essential quantitative and qualitative information on the various mineral deposits in the Commonwealth and are based on the latest published information and on unpublished information, obtained by correspondence where necessary, with various Commonwealth Surveys. So far, nineteen metals. and non-metals have been covered in this mannernamely, copper, lead, zinc, cobalt, nickel, antimony, -manganese, tungsten, vanadium, molybdenum, chromium, beryllium, zirconium, titanium, niobium and tantalum, phosphates, sulphur and asbestos. These are circulated to the United Kingdom Ministries concerned, to members of the Commonwealth Committee on Mineral Resources and Geology, the Defence Advisory Committee on Commonwealth Mineral Resources and to the Commonwealth scientific liaison officers at Africa House, London. It is hoped to cover the entire field of industrial minerals and rocks and, with certain modifications, to publish these reports in the form of a single volume.

Some preliminary action is being taken on the subject of the presentations of mineral statistics, in order to explore the possibility of greater uniformity in the use of units and methods of presentation. The recommendation of the 1948 Specialist Conference asking all Commonwealth countries to prepare and issue an annual volume of abstracts of geological papers of the territories under their control has not yet been put into action by all the countries concerned. In order to assist in this work, the Geologicel Liaison Office has prepared such a volume of United Kingdom abstracts for 1951 for limited distribution, which will be followed by that for 1952. If this experiment is successful, an attempt will be made to extend this work to those countries of the British 
Commonwealth which are not already preparing their own annual volumes of abstracts.

The geological liaison officer serves on a number of committees concerned with mineral resources, their development and utilization. The officer, as a specialist on the subject of geology and mineral resources, also acts in close liaison with the scientific liaison officers of the other Commonwealth countries, and at the same time close liaison is maintained.with the Ministry of Materials, Department of Scientific and Industrial Research and other Ministries in Great Britain which are interested in the mineral resources and their availability throughout the Commonwealth. Reports and accounts of meetings and conferences concerned with geology and mineral resources are also prepared and circulated to the Commonwealth countries.

Close contact is maintained by the Geological Liaison. Office with the Colonial Geological Surveys Directorate, as the two organizations are in a sense complementary; the latter links all the Colonial Geological Surveys, while the former is an attempt to link, in a less formal way, the Commonwealth Geological Surveys. The Geological Liaison Office is now charged, as a result of recommendations by the British Scientific Official Conference in Australia, with the formation of Commonwealth collaboration on geophysical prospecting, and the beneficiation and utilization of low-grade ores. The Office is now firmly established as an intrinsic part of the British Commonwealth Scientific Office, and, as an experiment in a purely Commonwealth organization, appears to be functioning with some measure of success.

\section{RECORDING OF RESEARCH AND ITS PATENT ASPECTS}

$\mathrm{M}$

ANY research workers, more usually the younger ones, dislike keeping adequate records of their investigations, but the fact has to be faced that the keeping of proper records is probably much more important, and a much less simple obvious matter, than is often supposed. Various aspects of the subject were discussed last year by a joint committee of the Franklin Institute and of the American Patent Law Association in a programme entitled "Who is the First Inventor ?" ; and further consideration has been given in a recent timely and interesting article by J. G. Jackson, on "Records of Research" ( $J$. Franklin Inst., 254, 355; 1952).

There are, of course, several sound reasons for keeping good records, many of which are sufficiently obvious without undue elaboration. (a) Avoidance of duplication, especially in prolonged research, when problems may again crop up that have been already studied and not recorded. (b) Taking full advantage of negative results, which also may prevent duplication if properly noted at the time. (c) Assisting the development of a fundamental approach, for very often at the start the workers are somewhat in the dark, or are taking part in one small section of a comprehensive programme, so that they think their results are relatively unimportant and not worth reporting; but such data later on prove essential in developing a theory or fundamental approach. (d) Publication; when work is published or reported at a meeting, supplementary questions arise which cannot be answered because full data have not been recorded. (e) Patent requirements; for example, insufficient record prevents the inventor from establishing that he was the first inventor, and it may thus happen that the company which developed the subject-matter may be forced to take a licence under someone else's patent.

The very minimum of information that should be recorded is the date of commencement of work, by whom it is done, detailed account of the work (with date of each important step) and the results. Such recording may often be the proper function of the research director or group supervisor. For patent purposes it is absolutely essential that provision be made for corroboration, and this is discussed at some length by Mr. Jackson. Some useful practical notes on this part of the subject can be found elsewhere ${ }^{1,2}$,

Certain milestones in connexion with research in industry should be formalized, to enable firms to determine the progress being made and the status at each stage. These formal steps are very helpful in tying together various records for patent purposes; and assigning project numbers is, for the same reason, of great assistance.

Several valuable suggestions on the keeping of laboratory notebooks are given : step-by-step records in order of time; making of sketches and drawings ; issuing a specification on an item under development before it is standardized (which constitutes a valuable record of research) ; photographs and samples ; and codes and abbreviations. These last-named may often be the cause of much trouble and confusion, some curious examples of which are given. Special records may sometimes be required from the point of view of patents, on which much useful advice is provided. Finally, it is pointed out that publications perform certain functions as research records, and have a special significance in patent matters.

${ }^{1}$ Kapp, "Laboratory Notebooks", 33 JPOS (J. Pat. Off. Soc., 502 (1951). "Tuska, "Patent Notes for Engineers", 3rd edit. (Radio Corp.
America, 1947).

\section{ELECTRONIC DIGITAL COMPUTERS}

\section{CONFERENCE IN THE UNITED STATES}

IN 1950 a meeting was held in Atlantic City, N.J., to discuss electron tubes for computers. The meeting was initiated by Dr. A. L. Samuel, as representative of the Research Development Board, and was sponsored by the American Institute of Electrical Engineers and the Institute of Radio Engineers. 'The success of this initial meeting led Prof. J. G. Brainerd to suggest the formation of a joint computer conference committee between these two last-named bodies in order to consider whether further meetings should be held and, if so, on what subjects. It was decided that the subjects which required urgent attention were electronic digital computers, input and output equipment, high-speed memory and choice of number system. Accordingly, the joint conference held in Philadelphia, Penn., during December 10-12, 1951, dealt with the first topic, and a recent conference, during December 10-12, 1952, at New York City, was concerned with input and output equipment.

The 1951 meeting, at which the Association for Computing Machinery also co-operated, attracted an attendance of 877 members, and the eighteen papers 